O. V. Maksymovych ${ }^{1}$, Dr. Sc. (Tech.), Prof., orcid.org/0000-0002-2892-7735,

A. R. Dzyubyk ${ }^{2}$, Cand. Sc. (Tech.), Assoc. Prof., orcid.org/0000-0003-2091-171X,

Kh. A. Barvinska ${ }^{2}$, Cand. Sc. (Tech.),

orcid.org/0000-0003-3464-3728,

L. V. Dzyubyk ${ }^{2}$, Cand. Sc. (Tech.),

orcid.org/0000-0001-6942-9436
1 - University of Science and Technology, Bydgoszcz, Poland, e-mail: olesyamax@meta.ua

2 - Lviv Polytechnic National University, Lviv, Ukraine, e-mail: dar.lviv@gmail.com; hristinabarvinska@gmail.com; liudmyla.v.dziubyk@lpnu.ua

\title{
DETERMINATION OF STRESS IN COMPOSITE PLATES WITH CRACKS ON THE BASIS OF THE METHOD OF INTEGRAL EQUATIONS AND SOLUTIONS BY GREEN
}

Purpose. To construct singular integral equations based on solutions of the Green problem and to develop a method for calculating stresses in the vicinity of cracks in anisotropic plates of complex form.

Methodology. The investigation was carried out using the theory of elasticity of anisotropic bodies and the method of integral equations. The numerical algorithm for solving the constructed equations was based on Lobatto quadrature formulas.

Findings. The method of determination of stresses near cracks in plates of complex form was developed with the help of the apparatus of integral equations. The kernel of the equations were constructed on Green's solutions, which makes it possible to satisfy automatically the boundary conditions on the given contours. Green's solutions were presented and the integral equations were constructed on their basis for the half-plane with a free or rigidly fixed boundary and plates with an elliptical hole, which are weakened by cracks. Also the investigation of stress intensity factors was performed for a system of cracks placed near a straight-line boundary in a half-plane or near an elliptical hole in a plate.

Originality. In the article a method for calculating the stress-strain state in anisotropic plates of complex form based on a device of singular integral equations was proposed, the kernels of which are constructed on Green's solutions. Its efficiency is illustrated while considering the plates of various forms with cracks.

Practical value. The results of the research presented in this work can be used in calculations of the strength of composite plates of complex form with cracks. The results of the performed calculations give an opportunity to predict the limit equilibrium of composite plates with cracks located close to its straight-line and elliptic boundaries.

Keywords: composite plate, stress intensity factor (SIF), cracks, singular equations, Lobatto quadrature formulas

To determine the stress-strain state of anisotropic plates with holes and cracks, the method of boundary integral equations (BIEM) is widely used. In literature, the most widespread approach is with application of Somiliano identity, which transforms such tasks into solving hypersingular integral equations [1].

In the book [2] a sufficiently complete overview of the studies performed in this direction is given. Methods for solving such equations that are rather complex are given in this book and in papers $[3,4]$. For studies of stresses at cracks in isotropic materials, simpler methods based on singular integral equations are more widely used in literature [5]. For anisotropic plates, similar equations are constructed, which have a more complex form [6].

The equations were constructed in relation with of derivatives from displacement discontinuity on the edge cracks for a partial case of anisotropy and described in [7].

In [8] for these problems singular integral equations were constructed in relation with displacement discontinuity on the edge cracks that have a simple look. In constructing these equations, the dependencies [9] between the Lekhnitskii complex potentials, stress and displacements are used. Similar equations by another method are constructed in [10].

Investigation of stresses near cracks in the plates of complex form with general algorithms BIEM in some cases is complicated. For example, one of the boundaries of the plate is infinite (in particular, tasks for the half-plane); cracks are located close to the hole etc. Therefore, for some particular types of tasks modified integral equations using Green's solutions are constructed, which allow satisfying the conditions on the chosen boundary identically [5].

In the article, a general approach to the construction of modified integral equations for anisotropic plates of different

(C) Maksymovych O. V., Dzyubyk A. R., Barvinska Kh.A., Dzyubyk L. V., 2019 geometric shapes and weakened by systems of cracks is proposed. This enables to diagnose effectively the technical equipment with defects [11] and to predict its subsequent exploitation [12].

Let us consider an anisotropic plate that occupies a certain domain $D$, mark the contour by which the domain is limited with $L_{D}$ and note that this contour can be an external boundary for bounded plates or as border of the hole. Let us assume that the plate is weakened by the cracks placed along the contours $L_{j}, j=1, \ldots, J$ and also let us accept that the plate is under the action of constant forces at infinity (for plates of infinite size) and is loaded with concentrated forces.

The main ratio. Let us first consider an infinite plate with cracks located along the curves $L_{j}, j=1, \ldots, J$, the plate is under the forces at infinity and concentrated forces. By $q_{G}(z)=X_{G}+$ $+i Y_{G}$ we denote a vector of the stress on an arbitrary curve $G$, which belongs to the plate. On the basis of [9] this vector is determined with the formula,

$$
\begin{aligned}
& \left.q_{G}=\left(s_{1}-i\right) z_{1}^{\prime} \Phi\left(z_{1}\right)+\overline{\left(\overline{s_{1}}\right.}-i\right) \overline{z_{1}^{\prime}} \overline{\Phi\left(z_{1}\right)}+ \\
& \quad+\left(s_{2}-i\right) z_{2}^{\prime} \Psi\left(z_{2}\right)+\left(\overline{s_{2}}-i\right) \overline{z_{2}^{\prime} \Psi\left(z_{2}\right)},
\end{aligned}
$$

where $\Phi\left(z_{1}\right), \Psi\left(z_{2}\right)$ are Lekhnitskii potentials, $z_{j}=x+s_{j} y, z_{j}=$ $=d z_{j} / d s ; s_{j}$ are the roots with a positive imaginary part of the characteristic equation $\Delta(t)=0, j=1,2 ; \Delta(t)=\alpha_{11} t^{4}-2 \alpha_{16} t^{3}+$ $+\left(2 \alpha_{12}+\alpha_{66}\right) t^{2}-2 \alpha_{26} t+\alpha_{22} ; \alpha_{\mathrm{ij}}$ are elastic constants in Hooke's law; $\sigma_{x}, \sigma_{y}, \tau_{x y}$ are forces; $\varepsilon_{x}, \varepsilon_{y}, \gamma_{x y}$ are strains; $d s$ is differential of the arc on the curve $G$.

Let us construct modified singular integral equations for plates of different shapes.

We choose a positive directions of moving on the curves $L_{j}$, $j=1, \ldots, J$. Let us designate displacement discontinuity as $(u, v)$ on the cracks by $g_{1}=u^{+}-u^{-}, g_{2}=v^{+}-v^{-}$. Here the values with the sign $(+)$ belong to the left edge of the cracks in relation to 
the chosen line of moving and to the right with the sign (-). On the basis of the correlations established in [9] between the potentials of Lekhnitskii and the stresses as well as displacements and the Cauchy theorem, for this case for the Lekhnitskii potentials we have integral representations.

$$
\begin{gathered}
\Phi\left(z_{1}\right)=\int_{L}\left[g_{1}^{\prime} \Phi_{1}\left(z_{1}, t_{1}\right)+g_{2}^{\prime} \Phi_{2}\left(z_{1}, t_{1}\right)\right] d s+\Phi_{S}\left(z_{1}\right) ; \\
\Psi\left(z_{2}\right)=\int_{L}\left[g_{1}^{\prime} \Psi_{1}\left(z_{2}, t_{2}\right)+g_{2}^{\prime} \Psi_{2}\left(z_{2}, t_{2}\right)\right] d s+\Psi_{S}\left(z_{2}\right),
\end{gathered}
$$

where $g_{1,2}=d g_{1,2} / d s, t_{j}=\xi+s_{j} \eta, j=1,2,(\xi, \eta) \in L-$ coordinates for which integration are carried out, $L=L_{1}+L_{2}+\ldots+$ $+L_{J}$

$$
\begin{gathered}
\Phi_{1}\left(z_{1}, t_{1}\right)=\frac{A_{1}}{t_{1}-z_{1}} ; \quad \Phi_{2}\left(z_{1}, t_{1}\right)=\frac{A_{2}}{t_{1}-z_{1}} ; \\
\Psi_{1}\left(z_{2}, t_{2}\right)=\frac{B_{1}}{t_{2}-z_{2}} ; \quad \Psi_{2}\left(z_{2}, t_{2}\right)=\frac{B_{2}}{t_{2}-z_{2}} .
\end{gathered}
$$

Here $\Phi_{S}, \Psi_{S}$ are solutions of the problem of the theory of elasticity for a continuous plate (without cracks), which take into account the applied load,

$$
\begin{gathered}
A_{1}=-\frac{i s_{1}}{2 \pi \Delta_{1}} ; \quad A_{2}=\frac{i}{2 \pi \Delta_{1}} ; \quad B_{1}=-\frac{i s_{2}}{2 \pi \Delta_{2}} ; \quad B_{2}=\frac{i}{2 \pi \Delta_{2}} ; \\
\Delta_{1}=\alpha_{11}\left(s_{1}-s_{2}\right)\left(s_{1}-\overline{s_{1}}\right)\left(s_{1}-\overline{s_{2}}\right) ; \\
\Delta_{2}=\alpha_{11}\left(s_{2}-s_{1}\right)\left(s_{2}-\overline{s_{1}}\right)\left(s_{2}-\overline{s_{2}}\right) .
\end{gathered}
$$

Consider the stress-strain state (SSS), which corresponds to the potentials $\Phi_{j}\left(z_{1}, a_{1}\right), \Psi_{j}\left(z_{2}, a_{2}\right)$ when $a_{j}=a_{R}+s_{j} a_{I}$, where $a=a_{R}+i a_{I}$ is a random point, $a \in D, j=1,2$. On the basis of [9], it follows that the main vector, which corresponds to the potentials $\Phi_{1}, \Psi_{1}$ and $\Phi_{2}, \Psi_{2}$, and the moment of forces at an random contours, which limits point $a$, are equal to zero. At a complete counter clockwise rotation around point $a$ along random curve $G$ the displacements which correspond to these potentials endure discontinuity accordingly $\left[u_{1}+i v_{1}\right]_{G}=1$, $\left[u_{2}\right.$ $\left.++i v_{2}\right]_{G}=i$. To wit, the potentials $\Phi_{j}, \Psi_{j} j=1,2$ belong to a class of dislocation solutions. Specifically, it follows from this that the displacements which corresponds to potentials (2) really have displacement discontinuity $\left(g_{1}, g_{2}\right)$ on the curve $L$.

Modified integrated representations. Let us consider now a case when an elastic anisotropic plate occupies a given domain $D$ and its boundary is traction-free. Also let us construct the integral equations for such a plate with the cracks in a way when the conditions on the boundary of domain $D$ are performed automatically. We construct Lekhnitskii's potentials $\Phi_{j}^{D}, \Psi_{j}^{D} \quad(j=1,2)$, to compose modified integral equations, which are the solutions of the task of the theory of elasticity for the domain $D$ with a load-free boundary (without cracks), with the poles at the point $\left(x_{0}, y_{0}\right)$,

$$
\Phi_{j}^{D} \sim-\frac{A_{j}}{z_{1}-z_{10}} ; \quad \Psi_{j}^{D} \sim-\frac{B_{j}}{z_{2}-z_{20}},
$$

where $z_{10}=x_{0}=s_{1} y_{0} ; z_{20}=x_{0}+s_{2} y_{0} ;\left(x_{0}, y_{0}\right) \in D$.

Let us denote this potentials by $\Phi_{j}^{D}\left(z_{1}, T\right), \Psi_{j}^{D}\left(z_{2}, T\right), j=$ $=1,2$, where $T$ is the point with the coordinates $\left(x_{0}, y_{0}\right)$.

A general solution to the problem of the theory of elasticity for the domain $D$ with cracks will be determined in such a form

$$
\begin{aligned}
& \Phi\left(z_{1}\right)=\int_{L}\left[\Phi_{1}^{D}\left(z_{1}, T\right) g_{1}^{\prime}(s)+\Phi_{2}^{D}\left(z_{1}, T\right) g_{2}^{\prime}(s)\right] d s+\Phi_{D}\left(z_{1}\right) \\
& \Psi\left(z_{2}\right)=\int_{L}\left[\Psi_{1}^{D}\left(z_{2}, T\right) g_{1}^{\prime}(s)+\Psi_{2}^{D}\left(z_{2}, T\right) g_{2}^{\prime}(s)\right] d s+\Psi_{D}\left(z_{2}\right),
\end{aligned}
$$

where $\Phi_{D}\left(z_{1}\right)=\Phi_{D}^{P}\left(z_{1}\right)+\Phi_{D}^{\infty}\left(z_{1}\right), \Psi_{D}\left(z_{2}\right)=\Psi_{D}^{P}\left(z_{2}\right)+\Psi_{D}^{\infty}\left(z_{2}\right)$; $T$ is point $(\xi, \eta)$, on which the integration is carried out.
Here the potentials $\Phi_{D}^{\infty}, \Psi_{D}^{\infty}$ and $\Phi_{D}^{P}, \Psi_{D}^{P}$ are the solutions for the continuous domain $D$ in which load attached to the plate is taken into account.

The potentials $\Phi_{j}^{D}\left(z_{1}, T\right), \Psi_{j}^{D}\left(z_{2}, T\right)$ consist of singular functions $\Phi_{j}\left(z_{1}, t_{1}\right), \Psi\left(z_{2}, t_{2}\right), j=1,2$, which are introduced above concerning the infinite plates and regular functions That is why the same displacement discontinuity on $L$ curve corresponds to the ratios (6) and (2). Moreover, by construction, the potentials (6) identically satisfy the condition of absence of stresses on the boundary of domain $D$ at arbitrary functions $g_{1}^{\prime}, g_{2}^{\prime}$.

We will require the forces on the sides of the crack defined by formula (1) by the potentials (6) to be equal to those given on it, which we denote by $X_{L}, i Y_{L}$. Thus, we obtain integral equations for determining functions $g_{1}^{\prime}(s), g_{2}^{\prime}(s)$ using the Plemelj-Sohotskyi formula in the form

$$
\int_{L}\left[g_{1}^{\prime}(s) Q_{1}(Z, T)+g_{2}^{\prime}(s) Q_{2}(Z, T)\right] d s=Q(Z) ; \quad Z \in L,
$$

where $Q(Z)=Q_{L}(Z)-Q_{D}(Z) ; Q_{j}(\mathrm{Z}, T)$ and $Q_{D}(Z)$ are vectors of the stresses $q_{L}$ at point $Z$ with the $(x, y)$ coordinates at the $L$ curve, defined by the formula (1) by, accordingly, complex potentials $\Phi_{j}^{D}\left(z_{1}, T\right), \Psi_{j}^{D}\left(z_{2}, T\right), j=1,2 \quad$ and $\Phi_{D}\left(z_{1}\right), \quad \Psi_{D}\left(z_{2}\right)$; $Q_{L}(Z)=X_{L}+i Y_{L}$.

Note that in order to implement the proposed approach there is no need to write out the kernel of the integral equations for each new domain - it is enough to write separately the ratio for the determination of stresses which correspond to the dislocation potentials.

The solution of singular integral equations was carried out by the mechanical quadrature method, in which the integrals were calculated with the aid of Lobatto's quadrature formulas [8].

The construction of auxiliary (dislocation) solutions. Let us consider the task of determining the functions $\Phi_{j}^{D}\left(z_{1}, T\right)$, $\Psi_{j}^{D}\left(z_{2}, T\right)$, where $T$ is the point $\left(x_{0}, y_{0}\right) \in D, D$ is the domain, which takes the plate. We introduce complex potentials $\Phi_{0}\left(z_{1}\right)$, $\Psi_{0}\left(z_{2}\right)$ to determine them for $D$ domain, provided that these have the following singularities

$$
\Phi_{0}\left(z_{1}\right) \sim \frac{A}{z_{1}-z_{10}} ; \quad \Psi_{0}\left(z_{2}\right) \sim \frac{B}{z_{2}-z_{20}},
$$

and the corresponding stresses on the boundary of domain $\mathrm{D}$ are equal to zero. Here $A, B$ are arbitrary complex constants; $z_{j 0}=x_{0}+s_{j} y_{0}, j=1,2$. If the potentials are constructed in this way, then the dislocation solutions would be

$$
\begin{aligned}
& \Phi_{j}^{D}\left(z_{1}, M\right)=-\left.\Phi_{0}\left(z_{1}\right)\right|_{A=A_{j}, B=B_{j}} ; \\
& \Psi_{j}^{D}\left(z_{2}, M\right)=-\left.\Psi_{0}\left(z_{2}\right)\right|_{A=A_{j}, B=B_{j}}, \quad j=1,2 .
\end{aligned}
$$

The investigation of the SSS of the half-plane with cracks. Let us consider a half-infinite plate $y<0$ with cracks. For the application of modified integral equations in the investigation of the SSS of the half-plane, it is necessary to derivate the respective dislocation solutions and the solutions for a continuous half-plane corresponding to the applied loading.

The dislocation solution for a half-plane with a free boundary using results $[8,9]$ is obtained at $j=1,2$

$$
\begin{gathered}
\Phi_{j}^{D}\left(z_{1}\right)=-\left(\frac{A_{j}}{z_{1}-z_{10}}+\alpha_{1} \frac{\bar{A}_{j}}{z_{1}-\overline{z_{10}}}+\beta_{1} \frac{\bar{B}_{j}}{z_{1}-\overline{z_{20}}}\right) ; \\
\Psi_{j}^{D}\left(z_{2}\right)=-\left(\frac{B_{j}}{z_{2}-z_{20}}+\alpha_{2} \frac{\bar{A} j}{z_{2}-\overline{z_{10}}}+\beta_{2} \frac{\bar{B}_{j}}{z_{2}-\overline{z_{20}}}\right),
\end{gathered}
$$




$$
\begin{gathered}
\alpha_{1}=\frac{\overline{s_{1}}-s_{2}}{\delta_{1}} ; \quad \beta_{1}=\frac{\overline{s_{2}}-s_{2}}{\delta_{1}} ; \quad \beta_{2}=\frac{s_{1}-\overline{s_{2}}}{\delta_{1}} ; \\
\alpha_{2}=\frac{s_{1}-\overline{s_{1}}}{\delta_{1}} ; \quad \delta_{1}=s_{2}-s_{1} .
\end{gathered}
$$

The dislocation solution for a half-plane with a rigidly fixed side using [9] will be obtained at $j=1,2$

$$
\begin{gathered}
\Phi_{j}^{D}\left(z_{1}\right)=-\left(\frac{A_{j}}{z_{1}-z_{10}}+\alpha_{1}^{\prime} \frac{\overline{A_{j}}}{z_{1}-\overline{z_{10}}}+\beta_{1}^{\prime} \frac{\overline{B_{j}}}{z_{1}-\overline{z_{20}}}\right) ; \\
\Psi_{j}^{D}\left(z_{2}\right)=-\left(\frac{B_{j}}{z_{2}-z_{20}}+\alpha_{2}^{\prime} \frac{\overline{A_{j}}}{z_{2}-\overline{z_{10}}}+\beta_{2}^{\prime} \frac{\overline{B_{j}}}{z_{2}-\overline{z_{20}}}\right),
\end{gathered}
$$

where

$$
\begin{gathered}
\alpha_{1}^{\prime}=\frac{\overline{q_{1}} p_{2}-\overline{p_{1}} q_{2}}{\delta_{2}} ; \quad \beta_{1}^{\prime}=\frac{\overline{q_{2}} p_{2}-\overline{p_{2}} q_{2}}{\delta_{2}} ; \\
\alpha_{2}^{\prime}=\frac{\overline{p_{1}} q_{1}-\overline{q_{1}} p_{1}}{\delta_{2}} ; \quad \beta_{2}^{\prime}=\frac{\bar{q}_{1} \bar{p}_{2}-\overline{q_{2}} p_{1}}{\delta_{2}} ; \\
\delta_{2}=q_{2} p_{1}-q_{1} p_{2} .
\end{gathered}
$$

The stress in a solid half-plane. Let us consider the case of the action of the concentrated force $(X, Y)$ applied at the point $\left(x_{0}, y_{0}\right)$. The corresponding potentials for the half-plane are determined by the formulas $(9,10)$ at

$$
A_{j}=-\frac{i\left(p_{1} X+q_{1} Y\right)}{2 \pi \Delta_{1}} ; \quad B_{j}=-\frac{i\left(p_{2} X+q_{2} Y\right)}{2 \pi \Delta_{2}} .
$$

The results of the calculations. Let us consider the halfplane with a straight-line crack, perpendicular to its boundary in greater detail. Let us accept (Fig. 1), the plate is loaded with the efforts $\sigma_{x}=p$, the edges of the crack are traction-free; crack length is $2 l$; the centre of the crack is at the $h$ distance from its boundary. We denote the tip closest to the boundary of the crack through the $A$ and remote through the $B$. Calculations



Fig. 1. Half-plane with a rectilinear crack

are done for isotropic and composite materials EF, LU, CF1, CF2, the elastic constants for which are given in Table 1 [9]. Coordinate system for the dates in Table 1 is selected so that the $O y$ axis is parallel to the direction with maximum stiffness of the material. It was assumed that the direction in which the modulus of elasticity is maximal is parallel to the axis $O y$. For the cases where this direction is rotated to a certain angle relative to the $O y$ axis, this angle is indicated in degrees near the name of the material.

In Table 2 the calculated relative SIF are given $F_{I}=$ $=K_{I} /(p \sqrt{\pi l})$ for tips of the crack at $h / l=1.1$ and $h / l=1.4$.

In the same table the results of calculations for edge cracks are given (at $h / l=1)$. In the last rows data for the edge cracks, which are placed periodically with the period d, are contained $d$. The calculation of the relative SIF $f_{I}=K_{I} /(p \sqrt{\pi 2 l})$ are done at $l / d=1$ and $l / d=2$.

The following conclusions can be made for the SIF values in an orthotropic plate with a perpendicular to the crack edge if the boundary is parallel to the orthotropic axis, from the data in the table: the SIFs are largest for isotropic plate; if the measure of anisotropy of the material which is being explored is increasing, then the SIF are decreasing; when the main axes are turning by $90^{\circ}$ the values of the SIFs do not change. For the system of periodically placed cracks, the value of the SIF are reduced. The SIFs in the anisotropic plate are smaller (larger) than in the isotropic plate, if the boundary is parallel to the direction with a smaller (higher) elastic modulus. For cracks located at an angle to the orthotropic axes, the SIF for anisotropic plate as well as isotropic plates may differentiate by several times.

Table 1

The elastic constants [9]

\begin{tabular}{|c|c|c|c|c|c|c|c|c|c|}
\hline & $E_{x}(\mathrm{GPa})$ & $E_{y}(\mathrm{GPa})$ & $G_{x y}(\mathrm{GPa})$ & $v_{x y}$ & $v_{y x}$ & $W_{E}$ & $E_{y} / E_{x}$ & $\operatorname{Im}\left(s_{1}\right)$ & $\operatorname{Im}\left(s_{2}\right)$ \\
\hline $\mathrm{EF}$ & 21.00 & 32.8 & 5.70 & 0.210 & 0.134 & 2.003 & 1.562 & 0.4462 & 1.7934 \\
\hline $\mathrm{LU}$ & 10.80 & 96.0 & 2.61 & 0.210 & 0.024 & 12.150 & 8.889 & 0.1664 & 2.0157 \\
\hline $\mathrm{CF} 2$ & 15.00 & 232.0 & 5.02 & 0.280 & 0.018 & 17.323 & 15.467 & 0.1486 & 1.7117 \\
\hline $\mathrm{CF} 1$ & 8.62 & 400.0 & 2.80 & 0.350 & 0.008 & 52.829 & 46.404 & 0.0840 & 1.7483 \\
\hline
\end{tabular}

Table 2

The relative SIF $F(\lambda)$ for the rectilinear crack in the half-plane

\begin{tabular}{|l|c|c|c|c|c|c|c|c|c|}
\hline & Izo & CF1 & CF1-90 & CF2 & EF & LU -1 & LU -90 & LU -45 \\
\hline \multicolumn{7}{|c|}{$h / l=1.1$} \\
\hline$F I(A)$ & 1.2098 & 1.1447 & 1.1447 & 1.1571 & 1.1862 & 1.1559 & 1.1559 & 1.4021 \\
\hline$F I(B)$ & 1.7584 & 1.5744 & 1.5744 & 1.6136 & 1.6958 & 1.6100 & 1.6100 & 1.9720 \\
\hline \multicolumn{7}{|c|}{$h / l=1.4$} \\
\hline$F I(A)$ & 1.1117 & 1.0717 & 1.0717 & 1.0786 & 1.0962 & 1.0779 & 1.0779 & 1.2532 \\
\hline$F I(B)$ & 1.2544 & 1.1689 & 1.1689 & 1.1842 & 1.2219 & 1.1827 & 1.1827 & 1.4023 \\
\hline \multicolumn{7}{|l|}{$h / l=1 ; f_{I}$} \\
\hline $1 / d=2$ & 0.2830 & 0.2946 & 0.1129 & 0.2924 & 0.2385 & 0.1564 & 0.2700 & 0.4052 \\
\hline $1 / d=1$ & 0.3988 & 0.4161 & 0.1597 & 0.4126 & 0.3372 & 0.2212 & 0.3812 & 0.5720 \\
\hline
\end{tabular}


The table also shows the calculated SIFs for isotropic plates, which are consistent with the literature data [11]. Table 3 shows the calculated relative SIF (values $f_{I}=K_{I} / p \sqrt{\pi l}$ ) for an anisotropic half-plane with rigidly fixed boundary at perpendicular to boundary edge cracks.

Curvilinear cracks. Let us consider a half-infinite plate with a crack, which is located along the arc of a parabola or in stretching at infinity parallel to the boundary forces $\sigma_{x}^{\infty}=p$.

The parametric equation of the curve on which the crack is placed has the form $x+i y=\omega(t): \omega(t)=l\left[t+i \varepsilon\left(t^{2}-1\right)+i y_{c}\right]-$ for parabolic and $\omega(t)=l \frac{2 t-i \varepsilon\left(1-t^{2}\right)}{1+t^{2}}+i y_{c}-$ for half-ellipse crack respectively. Here $-1<t<1$; $l$ is a half distance between the tips of the crack; $\left(0, y_{c}\right)$ is the centre of the ellipse; $\varepsilon=\delta / l$; $\delta$ is the maximum distance between the points which belong to the crack and the segment connecting the tips of the crack. The results of the calculations of the dimensionless SIC $F_{I, I I}=K_{I, I I} /(p \sqrt{\pi l})$ for the right tip of the crack in the isotropic plate are given in Table 4. Here in the brackets the data from work [13], (which are obtained by another method) are given.

In Table 5 the relative values of SIF for anisotropic halfplane with a crack along the arch of an ellipse are given.

Also the calculations for the half-plane were made, when the main axes of orthotropic are directed at an angle of 450 to the half-plane boundary. This case is typical for general anisotropy (no orthotropic material). The following conclusions can be made from the conducted research and the data in the tables. In general, the character of the SIF distribution in the anisotropic half-plane is similar to that of the SIF in an isotropic half-plane: with the increase in the curvature (convexity) of the crack the value of the $K_{1}$ always increases with the approach of the crack to the limit of the half-plane, increases, except the case when the contour of the crack is close to the straight line. At a slight anisotropy (EF material), the stressed state at the tips of the crack differs a little from the isotropic case (with the increase in the distortion of the crack the difference is greater). If the stiffness of the material is larger in the direction of the normal to the tip of the crack, then the anisotropy affects less than when in the same direction the stiffness of the material is less, for materials with significant anisotropy. For example, in the case of a crack located on a parabola for $\mathrm{CF} 2$ material, with $\varepsilon=0.5$ a relative deviation of the percentage of SIF values for anisotropic and isotropic plates, is $\partial \approx$ $\approx 0.2 \%$. At the same time, for the material CF $1-90-\partial \approx 26 \%$. The value of the SIF for the crack located on an ellipse arc is larger than the corresponding SIF for a crack located along the arch of a parabola.

The system of the cracks. Let us consider an anisotropic half-plane with a free boundary, which is weakened by a system of collinear or parallel cracks, with a half-length $l$ with the tensile force $p$ parallel to the boundary. It is accepted that the collinear cracks (Fig. 2) are located on the axis $O y$ (which is perpendicular to the boundary), the distances between the centres of the cracks are equal $d=2.25 l$, the tip of the first crack is located at point A.

Calculations were made for a system of $\mathrm{N}$ cracks, at $N=1$, $2,3,5,10,20,30,40$. The relative SIFs are calculated for the

Table 3

The SIF values in the half-plane with a rigid boundary

\begin{tabular}{|c|c|c|c|c|c|c|c|c|}
\hline $\mathrm{M}$ & Izo & {$[11]$} & CF1 & CF190 & CF2 & EF & LU-1 & LU-90 \\
\hline$f_{I}$ & 0.8688 & 0.8653 & 0.5444 & 0.5447 & 0.5442 & 0.5779 & 0.5439 & 0.544 \\
\hline
\end{tabular}

Comparison of the SIF for the isotropic plate with the data in [11]

\begin{tabular}{|c|c|c|c|c|}
\hline \multirow{4}{*}{$\delta$} & \multicolumn{2}{|c|}{ Ellipse } & $F_{1}$ & $F_{I I}$ \\
\cline { 2 - 5 } & $F_{1}$ & $F_{I I}$ & $\lambda=0.5$ & $-0.1786(-0.179)$ \\
& \multicolumn{3}{|c|}{ Parabola } \\
\hline 0.2 & $0.3673(0.368)$ & $-0.0557(-0.056)$ & $0.0739(0.074)$ & $-0.2921(-0.292)$ \\
0.5 & $0.5301(0.531)$ & $-0.0800(-0.080)$ & $0.2840(0.284)$ & $-0.2437(-0.244)$ \\
1.5 & $0.7641(0.765)$ & $-0.0452(-0.045)$ & $0.6926(0.693)$ & $-0.1835(-0.184)$ \\
2.5 & $0.9556(0.956)$ & $-0.0233(-0.023)$ & $0.9221(0.922)$ & \\
\hline
\end{tabular}

The relative values of the SIF for anisotropic half-plane with a crack along the arch of an ellipse

\begin{tabular}{|c|c|c|c|c|c|c|c|}
\hline \multicolumn{8}{|c|}{$F_{I}(A)$} \\
\hline$\varepsilon$ & Izo & CF1 & CF1-90 & CF2 & EF & LU-1 & LU-90 \\
\hline $\begin{array}{l}0.2 \\
0.5 \\
1.0 \\
1.5 \\
2.0 \\
2.5\end{array}$ & $\begin{array}{l}0.3673 \\
0.5301 \\
0.6569 \\
0.7641 \\
0.8634 \\
0.9556\end{array}$ & $\begin{array}{l}0.3507 \\
0.5279 \\
0.6676 \\
0.7717 \\
0.8648 \\
0.9514\end{array}$ & $\begin{array}{l}0.2806 \\
0.3980 \\
0.5393 \\
0.6521 \\
0.7501 \\
0.8386\end{array}$ & $\begin{array}{l}0.3541 \\
0.5296 \\
0.6667 \\
0.7702 \\
0.8639 \\
0.9514\end{array}$ & $\begin{array}{l}0.3571 \\
0.4942 \\
0.6228 \\
0.7320 \\
0.8304 \\
0.9217\end{array}$ & $\begin{array}{l}0.3139 \\
0.4278 \\
0.5651 \\
0.6768 \\
0.7754 \\
0.8656\end{array}$ & $\begin{array}{l}0.3529 \\
0.5146 \\
0.6479 \\
0.7528 \\
0.8474 \\
0.9357\end{array}$ \\
\hline \multicolumn{8}{|c|}{$F_{I I}(A)$} \\
\hline $\begin{array}{l}0.2 \\
0.5 \\
1.0 \\
1.5 \\
2.0 \\
2.5\end{array}$ & $\begin{array}{l}-0.0557 \\
-0.0800 \\
-0.0631 \\
-0.0452 \\
-0.0329 \\
-0.0233\end{array}$ & $\begin{array}{l}-0.0606 \\
-0.0961 \\
-0.1053 \\
-0.0968 \\
-0.0841 \\
-0.0710\end{array}$ & $\begin{array}{c}-0.0065 \\
-0.0017 \\
0.0050 \\
0.0105 \\
0.0161 \\
0.0223\end{array}$ & $\begin{array}{l}-0.0595 \\
-0.0935 \\
-0.0961 \\
-0.0826 \\
-0.0677 \\
-0.0543\end{array}$ & $\begin{array}{l}-0.0428 \\
-0.0523 \\
-0.0357 \\
-0.0216 \\
-0.0109 \\
-0.0021\end{array}$ & $\begin{array}{c}-0.0173 \\
-0.0125 \\
-0.0020 \\
0.0061 \\
0.0130 \\
0.0195\end{array}$ & $\begin{array}{l}-0.0527 \\
-0.0784 \\
-0.0756 \\
-0.0616 \\
-0.0477 \\
-0.0356\end{array}$ \\
\hline
\end{tabular}






Fig. 2. Half-infinite plate with a system of collinear cracks

isotropic plate $F_{I}=K_{I} /(p \sqrt{\pi l})$ and in the lower tips of the cracks are shown by points in Fig. 3 for each crack, which are connected by the solid lines.

The total number of cracks is indicated near the curves, the numbers of cracks are indicated horizontally. The results of the calculations of the relative SIF in the upper tips of cracks are shown in the same figure, which are connected by dashed lines. The similar data for the composite plates from material CF1 are shown in Fig. 4. The SIFs for the material were the same as for the material CF1, which coincide with the data given in Table 1.

From Figs. 3, 4 we can see that the SIFs are maximum for the medium cracks. The SIF values are the smallest for the farthest cracks from the boundary.

The system of parallel equidistant edge cracks in length $2 l$ at a distance between them $0.25 \mathrm{l}$ is considered. The calculated relative SIFs $f_{I}=K_{I} /(p \sqrt{\pi 2 l})$, for the $\mathrm{N}$ isotropic plate for systems $1,3,5,7,11,21,41$ cracks beginning with the average (which corresponds to number 1), are presented in Fig. 3 by the dots. These dots are connected by the solid lines. The number of cracks is indicated near the corresponding curves. In the same drawing, the values of SIF for cracks in the plates of materials $C F 1, C F 1_{90}$, which are connected accordingly by crosshatched lines and dashed lines.



Fig. 3. The SIF for isotropic plate with the system of collinear cracks



Fig. 4. The SIF for the plate from CF1 material with the system of collinear cracks



Fig. 5. The SIFs for isotropic plate and the plate from the CF1, CF $1_{90}$ materials with the system of boundary parallel cracks 
It can be seen that the SIFs are not the same for the system of parallel cracks in materials $C F 1, C F 1_{90}$. The maximum SIFs are obtained on finite cracks, and these values decrease with increasing of number of the cracks. The SIFs in the case when the cracks are parallel to the direction with the greater rigidity of the material were closer to the SIFs in isotropic plates and were considerably smaller than those for the cracks perpendicular to this direction.

The SSS of the plates with elliptical holes and cracks. Let us consider a plate with a load-free elliptic hole with semiaxes $a$ and $b$, which lie on the coordinate axes $O x$ and $O y$ and show the dislocation and auxiliary potentials $\Phi_{D}\left(z_{1}\right), \Psi_{D}\left(z_{2}\right)$ for the continuous plate with a hole for application of modified integral equations.

Let us consider the task of determining the dislocation complex potentials (8) $\Phi_{0}\left(z_{1}\right), \Psi_{0}\left(z_{2}\right)$ for the domain $D$, which lies outside of the ellipse. Initials from these potentials

$$
\varphi_{0}\left(z_{1}\right)=\int \Phi_{0}\left(z_{1}\right) d z_{1} ; \quad \psi_{0}\left(z_{2}\right)=\int \Psi_{0}\left(z_{2}\right) d z_{2},
$$

based on (8), have the logarithmic features

$$
\varphi_{0}\left(z_{1}\right) \sim A \ln \left(z_{1}-z_{10}\right) ; \quad \psi_{0}\left(z_{2}\right) \sim B \ln \left(z_{2}-z_{20}\right) .
$$

To determine complex functions, we use the approach of (Hrylitskyi D. V.) work in which the problem for a plate with an elliptical hole, with the same concentrated force is considered. To solve the problem, the conformal mapping of the domain occupied by the plate and the mapping of auxiliary regions on the appearance of a single circle with the help of functions are used.

$$
z=\omega(\varsigma)=c \varsigma+d / \zeta ; \quad z_{j}=\omega_{j}\left(\varsigma_{j}\right)=c_{j} \varsigma_{j}+d_{j} / \varsigma_{j},
$$

where $c=\frac{a+b}{2} ; d=\frac{a-b}{2} ; \quad c_{j}=\frac{a-i s_{j} b}{2} ; d_{j}=\frac{a+i s_{j} b}{2} ; j=1,2$.

Using the results of the [4], we have

$$
\begin{aligned}
& \varphi_{0}\left(z_{1}\right)=A \ln \left(\varsigma_{1}-\varsigma_{10}\right)-\alpha_{1} \bar{A} \ln \left(\frac{\varsigma_{1}}{\varsigma_{1}-\varsigma_{10}^{*}}\right)-\beta_{1} \bar{B} \ln \left(\frac{\varsigma_{1}}{\varsigma_{1}-\varsigma_{20}^{*}}\right) ; \\
& \psi_{0}\left(z_{2}\right)=B \ln \left(\varsigma_{2}-\varsigma_{20}\right)-\alpha_{2} \bar{A} \ln \left(\frac{\varsigma_{2}}{\varsigma_{2}-\varsigma_{10}^{*}}\right)-\beta_{2} \bar{B} \ln \left(\frac{\varsigma_{2}}{\varsigma_{2}-\varsigma_{20}^{*}}\right),
\end{aligned}
$$

where

$$
\begin{gathered}
\alpha_{1}=\frac{\overline{s_{1}}-s_{2}}{\delta_{1}} ; \quad \beta_{1}=\frac{\overline{s_{2}}-s_{2}}{\delta_{1}} ; \quad \beta_{2}=\frac{s_{1}-\overline{s_{2}}}{\delta_{1}} ; \\
\alpha_{2}=\frac{s_{1}-\overline{s_{1}}}{\delta_{1}} ; \quad \delta_{1}=s_{2}-s_{1},
\end{gathered}
$$

variables $\varsigma_{j}$ and $\varsigma_{j 0}$ are determined by the values $z_{j}, z_{j 0}$ on the basis of correlations (11), $\varsigma_{j *}=1 / \overline{\varsigma_{j 0}}$.
We determine the dislocation potentials by differentiating

$$
\begin{gathered}
\Phi_{0}\left(z_{1}\right)=\left[\frac{A}{\varsigma_{1}-\varsigma_{10}}+\alpha_{1} \bar{A}\left(\frac{1}{\varsigma_{1}-\varsigma_{10}^{*}}-\frac{1}{\zeta_{1}}\right)+\right. \\
\left.+\beta_{1} \bar{B}\left(\frac{1}{\varsigma_{1}-\varsigma_{20}^{*}}-\frac{1}{\zeta_{1}}\right)\right] / \omega_{1}^{\prime}\left(\varsigma_{1}\right) ; \\
\Psi_{0}\left(z_{2}\right)=\left[\frac{A}{\varsigma_{2}-\varsigma_{20}}+\alpha_{2} \bar{A}\left(\frac{1}{\varsigma_{2}-\varsigma_{10}^{*}}-\frac{1}{\zeta_{2}}\right)+\right. \\
\left.+\beta_{2} \bar{B}\left(\frac{1}{\varsigma_{2}-\varsigma_{20}^{*}}-\frac{1}{\zeta_{2}}\right)\right] / \omega_{2}^{\prime}\left(\varsigma_{2}\right) .
\end{gathered}
$$

The auxiliary potentials which take into account the external load. Let us give additional solutions for the plate with an elliptical hole, which take into account the applied external load. Accept that the boundary contour is free of load, the plate is under the stretching forces $p$, the angle between the direction of the action of which and the axis $O x$ is equal to $\alpha$. The solution of the task in (Hrylitskyi D. V.) is obtained as a sum of two components. The first $\Phi_{\infty}, \Psi_{\infty}$ are the potentials for the continuous plate, which correspond to the applied load at infinity. The second component is determined through the Lekhnitskii complex potentials which are obtained using the conformal mapping, which have the form

$$
\begin{gathered}
\varphi\left(\varsigma_{1}\right)=-\frac{p}{4\left(s_{1}-s_{2}\right) \varsigma_{1}}\left[i b\left(s_{2} \sin 2 \alpha+2 \cos ^{2} \alpha\right)-\right. \\
\left.-a\left(2 s_{2} \sin ^{2} \alpha+\sin 2 \alpha\right)\right] ; \\
\psi\left(s_{2}\right)=\frac{p}{4\left(s_{1}-s_{2}\right) \varsigma_{2}}\left[i b\left(s_{1} \sin 2 \alpha+2 \cos ^{2} \alpha\right)-\right. \\
\left.-a\left(2 s_{1} \sin ^{2} \alpha+\sin 2 \alpha\right)\right] .
\end{gathered}
$$

The results of the calculations. For example, let us consider an anisotropic plate with an elliptical hole that is weakened by a rectilinear crack of the half-length $l$ with the centre at the point $(c, 0)$, which is inclined at an angle $\alpha$ to the $O x$ axis. Let us assume that the plate is stretched along the axis of $O y$ by the effort $p$. The relative values of the SIF, which are calculated $F_{I, I I}=K_{I, I I} /(p \sqrt{\pi l})$ for the plate which is made from the $\mathrm{CF} 1$ materials with the ratio of the semi axes $b / a=0.5$ at $c=$ $=1.2 a, l=0.1 a, \alpha=0$ (the crack lies on the axis $O x$ ) depending on the angle between the direction of the main axis of orthotropy and the crack, are depicted in Fig. 6. Here curves 1 and 3 show the value $F_{I}$ and $F_{I I}$ for the tip of the crack which is closest to the hole, and 2 and $4-$ for the remote one. For comparison, curves $1^{\prime}, 2^{\prime}$ depict the similar results for curves 1,2 for an isotropic plate (they do not depend on $\alpha$ ).

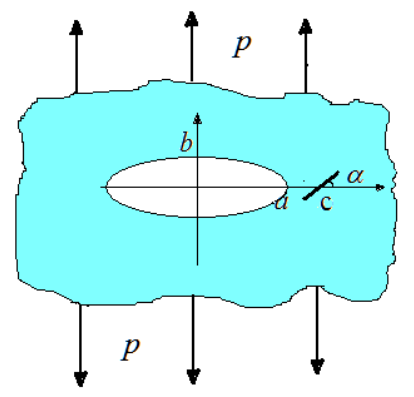

$a$



$b$

Fig. 6. Scheme of the problem (a). The SIF for the cracks in the anisotropic plate with a hole (b) 
From the figure it can be seen that the most significant impact of anisotropy in this case occurs when a crack is located at an angle of $45^{\circ}$ to the main axis of the orthotropy for a closer tip of the crack and when $\alpha=60^{\circ}-$ for a distant tip. The SIFs $K_{I I}$ also grow at these corners.

Let us consider the rectilinear crack inclining at an $\alpha$ angle to the $O x$ axis. The results of the calculations of the relative values of SIF in the tip $A$ vicinity to the hole and the remote tip $B$ at the angles of inclination of the crack 0 and $45^{\circ}$ are given in Table 6 .

It can be seen from the table that when the crack is located on the main axes of orthotropy the values of the SIF were close to the SIF for isotropic materials; moreover, for all considered materials they are smaller in value. But for the inclined crack, the values of the SIF are more significantly different for different materials (up to $2-3$ times).
Let us consider a plate with an elliptical hole and two rectilinear cracks in the half-length $L$ with the centres at $(-c, 0)$, $(c, 0)$ points and inclined to the $O x$ axis at angles 0 and $\alpha$. The calculated values of the relative SIF $F_{I, I I}=K_{I, I I} /(p \sqrt{\pi L})$ in the $A, B$ tips of the left crack and in the $C, D$ of the right cracks for the isotropic plate for stretching forces $p$ in the direction of the axis $O y$ are given in Table 7 for $a=b, c=2 a, L=0.8 a$. The analogical results for the plate which is made from the essentially anisotropic material $C F 1\left(C F 1_{90}\right)$ are given in Tables 8,9 .

The results presented in Table 7 are in good agreement with the directory [13] for the angular points $A$ and $B$ which are obtained by another method. For the right cracks at the corners $\alpha \sim 90^{\circ}$ the difference between the data increases. The listed SIF on the developed algorithm with different accuracy

The relative SIF for the crack near an elliptical hole

\begin{tabular}{|l|c|c|c|c|c|c|c|c|}
\hline \multirow{2}{*}{ Material } & \multicolumn{9}{|c|}{$\alpha=0^{\circ}$} & \multicolumn{4}{c|}{$\alpha=45^{\circ}$} \\
\cline { 2 - 9 } & $F_{I}(A)$ & $F_{I I}(A)$ & $F_{I}(B)$ & $F_{I I}(B)$ & $F_{I}(A)$ & $F_{I I}(A)$ & $F_{I}(B)$ & $F_{I I}(B)$ \\
\hline Izo & 2.452 & 0.0 & 1.913 & 0.0 & 0.994 & 0.541 & 0.915 & 0.402 \\
\hline CF1 & 2.191 & 0.0 & 1.747 & 0.0 & 0.387 & 0.655 & 0.351 & 0.593 \\
\hline CF1 $_{90}$ & 2.301 & 0.0 & 1.873 & 0.0 & 1.371 & 0.311 & 1.778 & 0.031 \\
\hline CF2 & 2.235 & 0.0 & 1.771 & 0.0 & 0.470 & 0.644 & 0.420 & 0.568 \\
\hline EF & 2.420 & 0.0 & 1.910 & 0.0 & 0.977 & 0.512 & 0.955 & 0.393 \\
\hline LU-1 & 2.341 & 0.0 & 1.882 & 0.0 & 1.120 & 0.427 & 1.261 & 0.258 \\
\hline LU-90 & 2.250 & 0.0 & 1.778 & 0.0 & 0.509 & 0.634 & 0.460 & 0.555 \\
\hline CF145 & 3.213 & 0.941 & 2.083 & 0.244 & 0.719 & 0.448 & 0.960 & 0.049 \\
\hline LU-45 & 2.882 & -0.51 & 2.060 & -0.18 & 1.716 & 0.827 & 1.057 & 0.536 \\
\hline
\end{tabular}

Table 7

The relative SIF for the isotropic plate with an elliptical hole and two rectilinear cracks

\begin{tabular}{|c|c|c|c|c|c|c|c|c|}
\hline$\alpha / \pi$ & $F_{I}(A)$ & $F_{I}(B)$ & $F_{I I}(A)$ & $F_{I I}(B)$ & $F_{I}(C)$ & $F_{I}(D)$ & $F_{I I}(C)$ & $F_{I I}(D)$ \\
\hline 0 & 1.2912 & 1.9314 & 0 & 0 & 1.9314 & 1.2911 & 0 & 0 \\
\hline 0.0556 & 1.2886 & 1.9254 & -0.0058 & -0.0067 & 1.8443 & 1.2396 & 0.2624 & 0.1592 \\
\hline 0.1111 & 1.2819 & 1.91 & -0.0108 & -0.0125 & 1.6061 & 1.1633 & 0.4543 & 0.3062 \\
\hline 0.1667 & 1.2731 & 1.8901 & -0.0143 & -0.0167 & 1.3383 & 1.0207 & 0.5629 & 0.4133 \\
\hline 0.2222 & 1.2637 & 1.869 & -0.0159 & -0.0186 & 1.0791 & 0.8508 & 0.6161 & 0.4691 \\
\hline 0.2778 & 1.2546 & 1.8489 & -0.0155 & -0.0182 & 0.8244 & 0.6609 & 0.6084 & 0.4651 \\
\hline 0.3333 & 1.2466 & 1.8314 & -0.0133 & -0.0156 & 0.5948 & 0.4856 & 0.5428 & 0.401 \\
\hline 0.3889 & 1.2404 & 1.8177 & -0.0096 & -0.0113 & 0.4106 & 0.3468 & 0.419 & 0.2805 \\
\hline 0.4444 & 1.2364 & 1.8091 & -0.005 & -0.0059 & 0.2923 & 0.2616 & 0.2523 & 0.1207 \\
\hline 0.5 & 1.2351 & 1.8062 & 0 & 0 & 0.24 & 0.240 & 0.0647 & -0.0647 \\
\hline
\end{tabular}

Table 8

The relative SIF for the plate from the CF1 material

\begin{tabular}{|c|c|c|c|c|c|c|c|c|}
\hline$\alpha / \pi$ & $F_{I}(A)$ & $F_{I}(B)$ & $F_{I I}(A)$ & $F_{I I}(B)$ & $F_{I}(C)$ & $F_{I}(D)$ & $F_{I I}(C)$ & $F_{I I}(D)$ \\
\hline 0 & 1.2023 & 1.6643 & 0 & 0 & 1.6643 & 1.2023 & 0 & 0 \\
\hline 0.0556 & 1.2006 & 1.6602 & -0.001 & -0.0014 & 1.5934 & 1.1653 & 0.2645 & 0.1979 \\
\hline 0.1111 & 1.1958 & 1.6491 & -0.0018 & -0.0026 & 1.4039 & 1.0609 & 0.4804 & 0.3713 \\
\hline 0.1667 & 1.189 & 1.6335 & -0.0023 & -0.0034 & 1.1467 & 0.9027 & 0.6201 & 0.4992 \\
\hline 0.2222 & 1.1814 & 1.616 & -0.0025 & -0.0036 & 0.8672 & 0.7104 & 0.6762 & 0.5661 \\
\hline 0.2778 & 1.174 & 1.5991 & -0.0024 & -0.0034 & 0.5991 & 0.5077 & 0.6525 & 0.5649 \\
\hline 0.3333 & 1.1674 & 1.5844 & -0.002 & -0.0029 & 0.3662 & 0.3186 & 0.5582 & 0.4961 \\
\hline 0.3889 & 1.1623 & 1.5731 & -0.0014 & -0.0021 & 0.1866 & 0.1651 & 0.4071 & 0.3672 \\
\hline 0.4444 & 1.1591 & 1.566 & -0.0007 & -0.0011 & 0.0731 & 0.0654 & 0.2174 & 0.1922 \\
\hline 0.5 & 1.158 & 1.5636 & 0 & 0 & 0.0325 & 0.0325 & 0.01 & -0.01 \\
\hline
\end{tabular}


The relative SIF for the plate from the $\mathrm{CF} 1_{90}$ material

\begin{tabular}{|c|c|c|c|c|c|c|c|c|}
\hline$\alpha / \pi$ & $F_{I}(A)$ & $F_{I}(B)$ & $F_{I I}(A)$ & $F_{I I}(B)$ & $F_{I}(C)$ & $F_{I}(D)$ & $F_{I I}(C)$ & $F_{I I}(D)$ \\
\hline 0 & 1.2823 & 1.8189 & 0 & 0 & 1.8189 & 1.2823 & 0 & 0 \\
\hline 0.0556 & 1.2805 & 1.8151 & -0.0003 & 0.0001 & 1.712 & 1.2902 & 0.4189 & -0.045 \\
\hline 0.1111 & 1.2749 & 1.8033 & -0.0006 & 0.0002 & 1.4501 & 1.3068 & 0.658 & -0.1073 \\
\hline 0.1667 & 1.2671 & 1.7872 & -0.0009 & 0.0002 & 1.2024 & 1.3167 & 0.6708 & -0.1243 \\
\hline 0.2222 & 1.2588 & 1.7702 & -0.0013 & 0 & 1.0338 & 1.3033 & 0.5716 & -0.1037 \\
\hline 0.2778 & 1.2511 & 1.7546 & -0.0015 & -0.0002 & 0.94 & 1.258 & 0.4412 & -0.0628 \\
\hline 0.3333 & 1.2446 & 1.7416 & -0.0015 & -0.0004 & 0.8966 & 1.1796 & 0.319 & -0.0234 \\
\hline 0.3889 & 1.2397 & 1.732 & -0.0013 & -0.0004 & 0.881 & 1.0817 & 0.2176 & -0.0044 \\
\hline 0.4444 & 1.2366 & 1.7261 & -0.0007 & -0.0003 & 0.8852 & 0.9864 & 0.1338 & -0.0186 \\
\hline 0.5 & 1.2356 & 1.7241 & 0 & 0 & 0.9177 & 0.9178 & 0.0652 & -0.0652 \\
\hline
\end{tabular}

did not change significantly the data given in the table. The same SIF values were also determined on the basis of the direct solving of the task, as for the isotropic plate, also appeared close to the data in Table 7.

The following conclusions can be made from the data tables: the SIF for anisotropic and isotropic plates are close to each other if the crack is parallel to the reinforced elements (the data in Tables 9 and 7 for the angular points A and B); the anisotropy substantially changes the SIF on inclined cracks near the hole.

The conclusions. The singular integral equations are determined in relation to the derivatives of displacement discontinuity on the edges of cracks based on the Green's solutions. The half-plane with a free or stiffly-fix boundary and an infinite plate with an elliptical hole weakened by cracks are considered in detail. The SIF for the single or for the system of rectilinear and curvilinear cracks are investigated. The effect of the plate's boundary and the anisotropy of the material on the stress near the cracks is analysed.

In particular, with the tensile of the orthotropic plate with a crack perpendicular to the edge the SIFs are the largest for the isotropic material. Anisotropy insignificantly affects the SIF for a crack which is located on the main axis of orthotropy near the elliptical hole. The value of the SIF for material $\mathrm{CF} 1$ is by 1.3 times greater than that of an isotropic plate for the cracks inclined at an angle of 45 to the axes of orthotropy.

\section{References.}

1. Tran, H. D., \& Mear, M. E. (2018). Calculation of T-stress for cracks in two-dimensional anisotropic elastic media by boundary integral equation method. International Journal of Fracture, 211(1-2), 149-162.

2. Ang, W. T. (2014). Hypersingular integral equations in fracture analysis. Elsevier.

3. Zhang, J., Lin, W., \& Dong, Y. (2019). A dual interpolation boundary face method for elasticity problems. European Journal of Mechanics-A/Solids, 73, 500-511.

4. Bej, M., Hota, M. K., \& Mohanty, P. K. (2016). On the Approximate Evaluation of Real Singular and Strongly Singular Integrals. Applied Mathematical Sciences, 10(3), 119-126.

5. Savruk, M.P., \& Kazberuk, A. (2016). Stress Concentration at Notches. Springer.

6. Kryvyy, O. F. (2014). Tunnel Internal Crack in a Piecewise Homogeneous Anisotropic Space. Journal of Mathematical Sciences, 52(1), 89-98.

7. Savruk, M. P., \& Chornen'kyi, A. V. (2015). Plane Problem of the Theory of Elasticity for a Quasiorthotropic Body with Cracks. Materials Science, 51(3), 311-321.

8. Maksymovych, O., Pasternak, Ia., Sulym, H., \& Kutsyk, S. (2014). Doubly periodic cracks in the anisotropic medium with the account of contact of their faces. Acta mechanica et automatic, 8(3), 160-164.

9. Maksymovych, O., \& Illiushyn, O. (2017). Stress calculation and optimization in composite plates with holes based on the modified integral equation method. Engineering Analysis with Boundary Elements, 83, 180-187.

10. Savruk, M. P., \& Kazberuk, A. (2014). Curvilinear Cracks in the Anisotropic Plane and the Limit Transition to the Degenerate Material. Materials Science, 50(2), 189-200.

11. Dzyubyk, A. R., Nykolyshyn, T. M., \& Porokhovs'kyi, Y. V. (2016). Influence of Residual Stresses on the Limit Equilibrium of a Pipeline with Internal Crack of Arbitrary Configuration. Materials Science, 52(1), 89-98.

12. Dreus, A., Kozhevnikov, A., Sudakov, A., \& Lysenko, K. (2016). Investigation of heating of the drilling bits and definition of the energy efficient drilling modes. Eastern-European Journal of Enterprise Technologies, 3(7(81)), 41-46.

13. Murakami, Yu. (Ed.) (1990). Stress intensity factor reference book. Vol. 1. Moscow: Mir.

\section{Визначення напружень у композитних пластинках із тріщинами на основі методу інтегральних рівнянь і розв'язків Гріна}

\section{О. В. Максимович ${ }^{1}$, А. Р. Дзюбик ${ }^{2}$, Х. А. Барвінська ${ }^{2}$, Л. В. Дзюбик ${ }^{2}$}

1 - Технологічно-природничий університет імені Яна і Єнджея Снядецьких, м. Бидгощ, Польща, e-mail: olesyamax@meta.ua

2 - Національний університет „Львівська політехніка“, м. Львів, Україна, е-mail: dar.lviv@gmail.com; hristinabarvinska@gmail.com; liudmyla.v.dziubyk@lpnu.ua

Мета. Побудувати сингулярні інтегральні рівняння на основі розв'язків задачі Гріна, а також розробити за їх допомогою методику розрахунку напружень в околі тріщин в анізотропних пластинках складної форми.

Методика. Дослідження здійснювалися 3 використанням теорії пружності анізотропних тіл і методу інтегральних рівнянь. Числовий алгоритм розв'язування побудованих рівнянь виконаний на основі квадратурних формул Лобатто.

Результати. Розроблена методика визначення напружень біля тріщин у пластинках складної форми за допомогою апарату інтегральних рівнянь. Ядра рівнянь побудовані на розв'язках Гріна, що дає змогу автоматично задовольняти визначенні граничні умови на заданих контурах. Наведені розв'язки Гріна та побудовані на їх основі інтегральні рівняння для півплощини з вільною 
або жорстко закріпленою межею та пластинки з еліптичним отвором, що послаблені тріщинами. Виконані дослідження коефіцієнтів інтенсивності напружень для системи тріщин, розміщених біля прямолінійної межі в півплощині або біля еліптичного отвору у пластинці.

Наукова новизна. У роботі запропонована методика розрахунку напружено-деформованого стану в анізотропних пластинках складної форми, що базується на апараті сингулярних інтегральних рівнянь, ядра в яких побудовано на розв'язках Гріна. Проілюстрована ії ефективність при розгляді пластинок різної форми із тріщинами.

Практична значимість. Наведені в роботі результати досліджень можуть бути використані в розрахунках на міцність композитних пластинок складної форми із тріщинами. Результати виконаних розрахунків дають можливість прогнозувати граничну рівновагу композитних пластинок із тріщинами, розміщеними біля прямолінійних або еліптичних ії меж.

Ключові слова: композитна пластинка, коефіцієнти інтенсивності напружень, тріщини, сингулярні рівняння, квадратурні формули Лобатто

\section{Определение напряжений в композитных пластинках с трещинами на основе метода интегральных уравнений и решений Грина}

\section{О. В. Максимович ${ }^{1}$, А. Р. Дзюбик ${ }^{2}$, К. А. Барвинская ${ }^{2}$, Л. В. Дзюбик ${ }^{2}$}

1 - Технологически-природоведческий университет имени Яна и Енджея Снядецких, г. Бидгощ, Польша, e-mail: olesyamax@meta.ua

2 - Национальный университет „Львовская политехника“, г. Львов, Украина, e-mail: dar.lviv@gmail.com; hristinabarvinska@gmail.com; liudmyla.v.dziubyk@lpnu.ua

Цель. Построить сингулярные интегральные уравнения на основе решений задачи Грина, а также разработать с их помощью методику расчета напряжений в окрестности трещин в анизотропных пластинках сложной формы.

Методика. Исследования проводились с использованием теории упругости анизотропных тел и метода интегральных уравнений. Числовой алгоритм решения построенных уравнений выполнен на основании квадратурных формул Лобатто.

Результаты. Разработана методика определения напряжений около трещин в пластинках сложной формы с помощью аппарата интегральных уравнений. Ядра уравнений построены на решениях Грина, что позволяет автоматически удовлетворять установленные граничные условия на заданных контурах. Приведены решения Грина и построенные на их основании интегральные уравнения для полуплоскости со свободной или жестко закрепленной границей, а также пластинки с эллиптическим отверстием, которые ослаблены трещинами. Выполнены исследования коэффициентов интенсивности напряжений для системы трещин, расположенных у прямолинейной границы в полуплоскости или у эллиптического отверстия в пластинке.

Научная новизна. В работе предложена методика расчета напряженно-деформированного состояния в анизотропных пластинках сложной формы, которая основана на аппарате сингулярных интегральных уравнений, ядра в которых построены на решениях Грина. Проиллюстрирована ее эффективность при рассмотрении пластинок различной формы с трещинами.

Практическая значимость. Приведенные в работе результаты исследований могут быть использованы в расчетах на прочность композитных пластинок сложной формы с трещинами. Результаты выполненных расчетов дают возможность прогнозировать предельное равновесие композитных пластинок с трещинами, расположенными у ее прямолинейных или эллиптических границ.

Ключевые слова: композитная пластинка, коэффициенты интенсивности напряжений, трещины, сингулярные уравнения, квадратурные формулы Лобатто

Рекомендовано до публікації докт. техн. наук Є. В. Харченком. Дата надходження рукопису 01.02.19. 